METHERLANDS YEARBOOK OT INTERNATIONAL LAW

\title{
$198 \%$
}




\section{Netherlands Yearbook of International Law}




\title{
NETHERLANDS YEARBOOK OF INTERNATIONAL LAW
}

\author{
published jointly with the \\ Netherlands International Law Review \\ and under the auspices of the \\ T.M.C. Asser Instituut, \\ Institute for International and European Law, \\ The Hague

\section{VOLUME XVIII \\ 1987}

MARTINUS NIJHOFF PUBLISHERS 
Under the combined subscription arrangements this volume of the Yearbook is linked to Volume 34 of the Netherlands International Law Review.

The Yearbook is available on subscription: Dfl. $135.00 /$ US $\$ 69.00 / £ 41.50$ per annual volume. Combined annual subscription to the Netherlands International Law Review and to the Netherlands Yearbook of International Law: Dfl. 244.00/US\$102.00 exclusive of postage and handling. Orders or requests for further information should be sent to: Martinus Nijhoff Publishers, c/o Kluwer Academic Publishers Group, Distribution Center, P.O. Box 322, 3300 AH Dordrecht, The Netherlands.

All correspondence with regard to the contents of the Yearbook should be addressed to the General Editors, T.M.C. Asser Instituut, 22 Alexanderstraat, 2514 JM The Hague, The Netherlands. The closing date for contributions is 1 August of the year prior to the year of publication (1 October for contributions in English). Contributions (which should be typed) should be submitted in triplicate.

The copyright is exclusively reserved to the author(s). Acceptance of a contribution by the Editors implies, however, acceptance by the author(s) of the condition that such contribution is subject to an embargo as regards publication elsewhere, either in English or in any other language, for a period of two years following publication of the Yearbook containing such contribution. Authors will not receive a fee, but will be presented with a copy of the Yearbook containing their contribution, together with 25 offprints of that contribution free of charge.

\author{
Printed in the Netherlands \\ (c) T.M.C. Asser Instituut, The Hague, 1987 \\ Library of Congress Catalog Card Number 72-623109
}

ISBN 90-247-3638-2

\author{
T.M.C. Asser Instituut \\ Institute for International and European Law \\ 20-22 Alexanderstraat, 2514 JM The Hague, Phone (0)70-630900, \\ Telex $34273 \mathrm{nl}$, Telefax 070 - 638171 \\ Director: C.C.A. Voskuil
}

Senior Staff: M. Sumampouw (Private International Law), Ko Swan Sik (Public International Law), A.E. Kellermann (Law of the European Communities), J.A. Swartzburg-Freedberg (International Commercial Arbitration), G.J. de Roode, Institute Manager (General Affairs), J.A. Wade (Legal Translations), M.H. Bastiaans (Publications), J.S. de Jongh (Library and Information).

The T.M.C. Asser Instituut was founded in 1965 by the Dutch universities offering courses in international law to promote education and research in the fields of law covered by the departments of the Institute: Private International Law, Public International Law, including the Law of International Organisations, Law of the european Communities and International Commercial Arbitration. The Institute discharges this task by the establishment and management of documentation and research projects, in some instances in co-operation with non-Dutch or international organisations, by the dissemination of information deriving therefrom and by publication of monographs and series. In addition, the Institute participates in the editing of the Yearbook Commercial Arbitration and in the editing and publishing of, inter alia, the Netherlands International Law Review and the Netherlands Yearbook of International Law. 


\section{BOARD OF EDITORS}

E.A. Alkema

University of Leiden

L.J. Bouchez

University of Utrecht

F. Kalshoven (General Editor)

University of Leiden

Ko Swan Sik (General Editor)

T.M.C. Asser Instituut

P. Morris

(Assistant General Editor)

T.M.C. Asser Instituut

GENERAL ADVISER

C.C.A. Voskuil

Director, T.M.C. Asser Instituut
P.J. Kuyper

Commission of the European

Communities

J.W. Schneider

Tilburg University

A.H.A. Soons

University of Utrecht

E.W. Vierdag

University of Amsterdam

K. Peters

(Editorial Assistant)

T.M.C. Asser Instituut

\section{HONORARY EDITOR}

H. Meijers

University of Amsterdam 
AA

Aanh. Hand. I/II

ABAJ

AFDI

AJIL

Annuaire

Art. J.

Bijl. Hand. I/II

BNB

Clunet

DD

(EC)OJ

ELD

GAOR

Hague Recueil

Hand. I/II

ICJ Reports

ICLQ

ILC Yearbook

ILM

KG

Law Am.

LNTS

LQR

NILR

NIPR

NJ

NJB

NJCM-Bulletin

NTIR

NYIL

PCIJ ser.A

Proc. ASIL

Rev. belge

RvdW

S\&S

Stb.

Stc.

Trb.

UNTS

Virg. JIL

WPNR

\section{Ars Aequi}

Aanhangsel tot het Verslag der Handelingen van de Eerste (Tweede)

Kamer der Staten-Generaal

American Bar Association Journal

Annuaire Français de Droit International

American Journal of International Law

Annuaire de l'Institut de Droit International

Art Journal

Bijlagen bij het Verslag der Handelingen van de Eerste (Tweede) Kamer der Staten-Generaal

Beslissingen in Belastingzaken - Nederlandse Belastingrechtspraak Journal du Droit International

Delikt en Delinkwent

Official Journal of the European Communities

European Law Digest

(United Nations) General Assembly Official Records

Recueil des Cours d l'Académie de Droit International de la Haye Verslag der Handelingen van de Eerste (Tweede) Kamer der StatenGeneraal

International Court of Justice, Reports of Judgments, Advisory Opinions and Orders

International and Comparative Law Quarterly

Yearbook of the International Law Commission

International Legal Materials

Kort Geding

Law America

League of Nations Treaty Series

Law Quarterly Review

Netherlands International Law Review

Nederlands Internationaal Privaatrecht

Nederlandse Jurisprudentie

Nederlands Juristenblad

NJCM [Nederlands Juristen Comité voor de Mensenrechten]

Bulletin - Nederlands Juristen Comité voor de Mensenrechten]

Nederlands Tijdschrift voor Internationaal Recht (now NILR)

Netherlands Yearbook of International Law

Permanent Court of International Justice, Advisory Opinions, Judgments and Orders

Proceedings of the American Society of International Law

Revue belge de droit international

Rechtspraak van de Week

Schip en Schade

Staatsblad van het Koninkrijk der Nederlanden

Nederlandse Staatscourant

Tractatenblad van het Koninkrijk der Nederlanden

United Nations Treaty Series

Virginia Journal of International Law

Weekblad voor Privaatrecht, Notarisambt (Notariaat) en Registratie 


\section{TABLE OF CONTENTS}

\section{Articles}

A. Broches, 1985 UNCITRAL Model Law on International Commercial Arbitration: an exercise in international legislation

H.W. Wefers Bettink, Open Registry, the Genuine Link and the 1986 Convention on Registration Conditions for Ships

$R$. Wolfrum, The Emerging Customary law of marine zones: State practice and the Convention on the law of the sea

P.J. Kuyper and K.C. Wellens, Deployment of cruise missiles in Europe: The legal battles in the Netherlands, the Federal Republic of Germany and Belgium

\section{Documentation}

Classification scheme

R.C.R. Siekmann, Netherlands state practice for the parliamentary year 1986-1987

M. Büchli, Treaties and other international agreements to which the Netherlands is a party

Ko Swan Sik and P.C. Tange, Netherlands municipal legislation involving questions of public international law

L.A.N.M. Barnhoorn, Netherlands judicial decisions involving questions of public international law

P.C. Tange, Dutch literature in the field of public international law and related matters, 1986

Table of cases

Index 